九州大学学術情報リポジトリ

Kyushu University Institutional Repository

State Policy and Use of Forest Resources in Vietnam : An Explanation by Habermas's Theory of Communicative Action

Quang Nguyen Vinh

Department of Forest and Forest Products Sciences, Faculty of Agriculture, Kyushu University

ABAD, Ricardo

Department of Sociology and Anthropology, Ateno de Manila University

SAT0, Noriko

Faculty of Agriculture, Kyushu University

https://doi.org/10.5109/10110

出版情報：九州大学大学院農学研究院紀要. 53 (1)，pp. 329-335，2008-02-28. Faculty of Agriculture, Kyushu University

バージョン :

権利関係 : 


\title{
State Policy and Use of Forest Resources in Vietnam: An Explanation by Habermas's Theory of Communicative Action
}

\author{
Nguyen Vinh QUANG ${ }^{1 *}$, Ricardo $\mathrm{ABAD}^{2}$, and Noriko $\mathrm{SATO}^{3}$ \\ Laboratory of Forest Policy, Division of Forest Environment and Management Sciences, \\ Department of Forest and Forest Products Sciences, Faculty of Agriculture, \\ Kyushu University, Fukuoka 812-8581, Japan \\ (Received November 9, 2007 and accepted November 30, 2007)
}

\begin{abstract}
In many places in Vietnam, despite the state policy attempting to protect, forest resources have been rampantly extracted and traded by local people. The study was formed to understand the interaction between the state and a local community in the management, use, and control of forest resources. An upland community in Northern Central Vietnam was chosen for the study. Findings were explained by the Habermas's theory of communicative action.

The study explored that the interaction between the state and the community has been marked by conflict: the state banned valued forest resource extraction, while the villagers persisted in extracting the resources which they have traditionally considered a source of livelihood and income. This communication, in Habermas's terms, is the colonization of the state over the community. The colonization, however, was not successful as the villagers subverted the state's intention and reconstituted their livelihood. They continued to extract and even trade forest resources despite threats of arrest and punishment.

The study further showed three major factors that enabled the reconstitution of livelihood of the villagers to thrive, which were (i) state mismanagement, or the inability of the state to enforce forest protection laws, (ii) network formation, or the ability of village residents to build and sustain linkages that made forest extraction a regular, systematic, and profitable enterprise, and (iii) collusion, or the involvement of state officials in forest extraction activities.
\end{abstract}

\section{INTRODUCTION}

Since the beginning of the 1990s, Vietnamese government has changed the forest management policy. Instead of directly managing forestland and forest resources, it has allocated them to local individuals. To implement this new forest land allocation (FLA) policy, two salient Decrees coded 02/CP and 01/CP were issued in 1994 and 1995, respectively, to guide allocating production and protection forestland to individual households (HHs). Recipients of production forest are encouraged to replant and manage the allocated forest for 50 years, and are allowed to use limited non-timber forest products (NTFPs) (Decree 02/CP 1994). While recipients of protection forest are to protect forest resources and be paid 50,000 VND (about $350 \mathrm{JPY}$ ) per hectare per year for first 5 years (Decree 01/CP 1995).

Along with the decrees, some attached programs were also established to back up the implementation of the policy. Among them were Program 327 and its follow-up one, Program 661 (MARD 2003).

Generally, the goals of the policy have been to encourage the protection and restoration of forest cover, to stop and limit local people from harmfully exploiting forestland and forest resources (Decree 02/CP 1994, Decree 01/CP 1995), and to improve livelihood of local

\footnotetext{
${ }^{1}$ Laboratory of Forest Policy, Division of Forest Environment and Management Sciences, Department of Forest and Forest Products Sciences, Faculty of Agriculture, Kyushu University

${ }^{2}$ Department of Sociology and Anthropology, Ateneo de Manila University, Quezon City 1108, Philippines

3 Faculty of Agriculture, Kyushu University

* Corresponding author (Email: nvquang@ffp.kyushu-u.ac.jp)
}

forest-related people (Decision 661/QD-TTg 1998).

As results of the policy, in some areas local people's control over land and land use increased, resulting in reforestation and greater benefits for forest planters (Cuc et al., 1996:67, Nhan 1998:12, Tuan 1998:39, Thu 1999:43, Thanh 2001:23), increase of forest landuse rights for local people (Nhan 1998:8), and increase of forest cover and quality (Viet 1998:14, Nhan 1998:12, Howard 1998:249, Bellamy 2000:2, Thanh et al., 2000:43-46, Huy 2003).

In other places, however, the policy failed in upland areas as FLA was not central of agricultural production and HH subsistence (Sunderlin and Ba 2005:20), especially for ethnic minority groups who are practitioners of shifting or swidden cultivation (San and Gilmour 1999:28, Castella et al., 2002:197). Despites the forest policy, villagers continued to widely reclaim primary forests for swidden cultivation (FPD 2006). Furthermore, villagers continued to log timber, although illegally, from natural forests, and overexploit NTFPs (Vien et al., 2005, FPD 2006). The World Bank (2002) reported that in Vietnam, despites the ban policy of the government, the amount of illegal logging is in the range of 0.5 to 2 million $\mathrm{m}^{3}$ per year. In short, Vietnam's forest cover and quality continue to be decreased.

Located in mountain region of Nghe An province, community of Lien Dinh, like other communities in the area, has strong connection with forest. It is even stronger as its settlement is in buffer zone of Pu Mat National Park (PMNP). Majority of the village residents are ethnic minorities who actively use forest resources not only for their own consumption but also for trade. Much of these acts of forest use, however, are prohibited 
by law, but village residents continue to exploit the forest (PMNP 2001). Despite the support given by the Social Forestry and Nature Conservation Project (SFNCP) ${ }^{\dagger}$ implemented in the PMNP and its buffer zones, the implementation of the Programs 327 and 661, and more especially, despite the enforcement of the Decrees 02/CP and 01/CP, local people still go to forests to cultivate their crops and graze their cattle, and to gather income-generating forest products such as fuel wood, mushroom, timber, wild animals, and the like (PMNP 2001).

Yet how have the local people been able to continue to extract forest resources, especially timber and NTFPs, while the government's intervention existed there? This is central question of this study.

\section{The Jurgen Habermas's Theory of Communicative Action}

In his "The Theory of Communicative Action," Habermas (1987) analyzes the relationships that exist between the lifeworld and the system. Habermas sees the lifeworld as the domain of "substantive rationality" in the social world, while the system is the domain of "formal rationality" that assaults the free discursive communication and action existing in the lifeworld. This assault is an attempt to "colonize" the lifeworld. To this colonization process, the lifeworld comes to be dominated by the system's formal rationality. The domination pursued by the central system and its steering media or (political) public sphere which is defined as a place where "the autonomy of the lifeworld has to prove itself in the face of the administrative system" (Habermas 1987:346). However, colonization does not always succeed in dominating the lifeworld. The lifeworld can resist the colonizing powers of the system and negotiate for better arrangements. It is possible also for the lifeworld to assimilate some notions and agreements from the system and accommodate with powers. In this manner, the lifeworld gets systematized or standardized through the formalization of rational communicative actions. This study thus examines the extent to which the system, represented by the Vietnamese state, colonizes the lifeworld, represented by the local community of Lien Dinh, in terms of forest resource management.

\section{Research Objectives}

Generally, the study aimed to understand the interaction between the state and a local community in the management, use, and control of forest resources. It particularly attempted (i) to identify present sources of living and livelihood of villagers under the new policy of FLA; (ii) to show how the policy has affected the livelihood of the community; and (iii) to examine why the vil- lagers persist in extracting forest resources despite state prohibition of this activity.

\section{MATERIALS AND METHODS}

A community named Lien Dinh located in Nghe An province, $380 \mathrm{~km}$ far from Hanoi, in northern central Vietnam was chosen for the study. It is a mountain forest-adjacent village and majority of its inhabitants are ethnic minorities. The situation of forest resource use and exploitation had been widespread in the community.

The study adapted an exploratory and descriptive design. It was conducted in 2001 and 2002 and employed the case study method. Both primary and secondary data were used, in which primary data were gathered by using the following techniques: semi-structured interview, in-depth interview, direct observation, and focused group discussion. Secondary data mostly came from documents and reports provided by local governmental forest-related offices.

Thirty-three informants, who are ordinary local people and representatives of local state agencies, were interviewed for the study. In details, those informants were village leader (1 person), vice village leader (1), head of agricultural production team (1), security cadre (1), community elders (3), timber loggers (4), NTFP gatherers (7) shop owners (3), forest resources traders (2), and representatives of various forest-related government agencies at locality (10 persons).

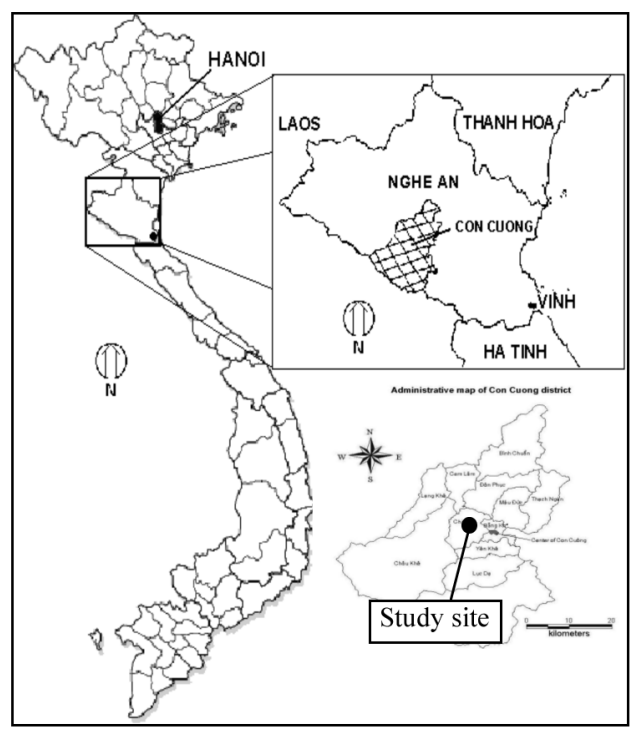

Fig. 1. Study site of Lien Dinh village.

RESULTS

\section{Profile of Community of Lien Dinh}

Lien Dinh community had been officially established

\footnotetext{
The SFNCP is a project jointly funded by the European Commission and Vietnamese government. It was formed in 1997 and its goal, among others, was to reduce destruction and degradation of forest resources in the PMNP area and its buffer zones (SFNCP 2002). To get the goal, the SFNCP conducted training courses to improve the local people's knowledge on environmental issues and agricultural intensification; and provided financial assistance to help local people generate income from sources rather than the forests. Lien Dinh village lies in buffer zone of this national park, thus it receives a lot of supports from the project.
} 
in 1967 and is located in a steep mountainous monsoon tropical area in Nghe An province, northern central Vietnam. It is in the buffer zone of the PMNP, and lies nearby the National Highway No. 7 which connects the community to Laos, other districts of the province, and other provinces in the lowlands. The proximity to the highway is seen as an advantage of the community to be linked with outsiders.

Demographically, as of December 2001 its population were 1,354 people grouping in $265 \mathrm{HHs}$. Of which 260 or $98.1 \%$ were the Thai minority, while the rest were the Dan Lai (4 HHs) and the Kinh (1 HH) ethnic groups. In terms of economic condition, Lien Dinh was a poor community with $52 \%$ of HHs experience food scarcity from 1 to 7 months a year (CPC 2002).

In terms of landuse, in 1,900 ha of natural land area, forestland takes a substantial portion (1,700 ha or 90\%), while agricultural paddy land occupies a small fraction (28.5 ha or $1.5 \%$ ). Comparing with other communities in the district, Lien Dinh has smaller land size but is the largest village in terms of population (DPC 2002). Of the total 1,700 ha of forestland, production forest accounts for 727 ha and protection forest occupies 973 ha. All production and protection forests were allocated to village HHs in 1997 and 2001, respectively (DPC 2002).

\section{Income Sources}

As for income source, HHs in Lien Dinh derived their incomes from 4 major sources: (1) agricultural production, (2) cattle and poultry raising, (3) petty business and service, and more importantly, (4) forest resources. Minor sources of income also came from salaries and wages as employees of the state or as hired workers.

Owing to the paucity of agricultural land, majority of Lien Dinh villagers had to use forestland to supplement food for consumption. Crops that they mainly cultivated on forestland (swidden field) were upland rice, maize, and cassava. Income from cattle and poultry also contributed a large share of the total $\mathrm{HH}$ income. However, not many HHs in the village had more than one cow, buffalo, or pig.

About business and service, Lien Dinh village was also home to 10 shops or stores that sold groceries and sundry items, traded in timber and NTFPs; and accepted contracts for home construction. In addition were places that milled rice, sewed clothes, and provided private motorcycles for hire. Four shop owners bought and sold NTFPs-among them bee's honey, geckoes, snakes, bamboo shoots, mushrooms, and even wild mammals. These were bought from villagers who illegally extracted these animals and products from the forest. The store owners sold these to other village residents or to outside traders.

Regarding income from forest resources, people in the village extracted from the forests flora resources such as timber, firewood, bamboo shoots, mushrooms, orchids, medicinal plants; and fauna resources such as bees, bee's honey, honeycomb, birds, deers, geckoes, snakes, and even porcupines. In other words, they extracted whatever kind of forest resources they could find. These resources contributed a very substantial role in meeting the people's basic needs, namely the materials for house building, fuel-wood for daily cooking, and food for survival. They were also the major sources of income that yielded larger amounts rather than the sum gained from agricultural production. However, it is important to note that extraction, trafficking, sale, and trading of such forest resources are considered illegal and should be fined, if exposed, according to the state law. Market prices of these forest resources are listed in Table 1.

Table 1. Average prices of forest resources extractors sold within the community

\begin{tabular}{|c|c|c|}
\hline $\begin{array}{l}\text { Kind of forest } \\
\text { resources }\end{array}$ & Unit & $\begin{array}{c}\text { Unit price } \\
(1,000 \mathrm{VND})\end{array}$ \\
\hline Timber* & $\mathrm{m}^{3}$ & $1,000-1,200$ \\
\hline (Dry) mushroom & $\mathrm{Kg}$ & 100 \\
\hline (Dry) bamboo shoot & $\mathrm{Kg}$ & $40-60$ \\
\hline Firewood & $20 \mathrm{~kg}$ & 2.5 \\
\hline Bee's honey & Litter & $35-40$ \\
\hline Swarm of bees** & Swarm & 100 \\
\hline Orchid & A plant & 50 \\
\hline Gecko & A gecko & 30 \\
\hline Snake** & A snake & $300-800$ \\
\hline Porcupine & $\mathrm{Kg}$ & 15 \\
\hline Deer & $\mathrm{Kg}$ & 60 \\
\hline
\end{tabular}

*In forests in Con Cuong district, the remaining valuable timber trees mainly were gioi (Talauma michelia hypolampra), gie (Quercus areca), and tro xanh (Ditercapus sp).

**For making so-called medicinal liquor.

Source: Field survey (2001, 2002).

\section{Forest Resource Extraction and Trading Activities}

Literally speaking, activities of forest resource extraction were overwhelmed in the community of Lien Dinh. Logging, hunting, and other types of forest resource extraction were common occurrences. One could easily buy jars or bottles of bee's honey, or several cubic meters of scarce timber or firewood in the village as long as one made advanced arrangements for their delivery with loggers or resource extractors, all of whom were village residents. Advanced arrangements were also needed to obtain certain kinds of animals like deer, porcupines, snakes, and geckoes. The sale of forest products was not only a profitable job but also, as in the words of an adult resident, "the easiest work in the area."

Forest extraction is illegal, yet villagers were willing to defy the law because they saw forest extraction as the most efficient and profitable means of survival. One old man claimed: "If we obeyed the state policies and absolutely not extract any forest resources, we would not be able to survive on such small plots of land for food production and with the very harsh and fluctuating weather condition of the area" (Field survey 2002).

But more than just survival, the amount of income people earned from timber trafficking, wild animal trading, and other illegal extraction activities was very much higher than the amount they got from legally-approved agricultural production activities. This is one major rea- 
son why local people in the village extracted so much forest resources. For instance, if one $\mathrm{HH}$ cultivated $2,000 \mathrm{~m}^{2}$ of paddy rice, and another $2,000 \mathrm{~m}^{2}$ of maize, they would need at least 5 workers to take care of the fields for 5 months for the paddy and up to 6 months for maize. In terms of cash, people on average would get 1.8 million VND for both paddy and maize. In sharp contrast, a group of 5 people could obtain this exact amount if they cut and sold timber after only 7 to 10 days of work, or if they sold 45 geckoes one person could catch after only 10 nights of hunting in the deep forest. In other words, forest extraction yields higher cash value per unit of time.

Villagers were usually sold collected forest products to shop owners, middlemen, or traders within the village. Those middlemen or traders then resold them to outside traders or collectors at much higher prices, which was usually from 40 to $60 \%$ or even up to more than $100 \%$ higher than the original cost.

\section{Impacts of the Decrees 02/CP and 01/CP, 327 and 661 Programs, and SFNCP in Lien Dinh Village}

The decrees, programs, and project had both positive and negative impacts to the livelihoods of Lien Dinh residents, as well as to its forest resources. Thanks to supports from the programs such as training courses on agricultural and forestry extensions, loan for production, provision of seedlings and nurslings (forest trees and agricultural crops) and stud animals, etc., Lien Dinh villagers had more knowledge on and investment in agricultural production. In the beginning, therefore, number of HHs seriously followed the guidelines set by the government and support agencies in agricultural production, forest protection and reforestation. As a results, they had more income from agricultural crops; they invested more labor and money into their allocated lands; forest planted areas increased owing to reforestation; swidden areas reduced; some HHs shifted from extensive traditional swidden farming to perennial fruit cultivation integrated with livestock production; and awareness on forest protection and conservation increased.

On the other hand, however, the implementation of allocating protection forest (with which a recipient will be paid 50,000 VND per ha per year) was conducted inconsistently, as those who were state officials or relatives of officials received much more protection forest than the ordinary and poor. Thirty five HHs in Lien Dinh community even were not allocated this land. In addition, demarcation of allocated plots, of both production and protection forests, among recipients were not clear either. This led to serious conflicts among the recipients. More seriously, recipients of forestlands were not assured of long-term benefit sharing, thus they rampantly conducted forest resource extraction activities.

\section{DISCUSSION}

While the government's policies were well-intended, the implementation had been uneven, confusing, and even impractical. As a result, the residents of Lien Dinh had little alternative but to resort back to forest extraction as a means of livelihood, oftentimes beyond the legal limits. Not only did the forest assure their survival, they argued, it was also an efficient source of income rather than cultivating rice or cassava in legally approved lands. They continued to engage in forest extraction, however, under threat of legal sanctions.

But, how have the residents of Lien Dinh been able to resist the law, defy state authorities, and continue to extract forest resources for profit and gain? Three major reasons were found which are (1) State mismanagement, or the inability of the state to enforce forest protection laws, (2) Network formation, or the ability of village residents to build and sustain linkages that make forest extraction a regular, systematic, and profitable enterprise, and (3) Collusion, or the involvement of state officials in forest extraction activities.

\section{State Mismanagement}

Poor compliance with duties and responsibilities

The Con Cuong District Forest Protection Unit (FPU), where Lien Dinh is located, has one checkpoint station. The station is open 24 hours a day regardless of holidays. Cadres in this station divide themselves into 3 groups and work on 3 shifts a day to patrol and check on the vehicles passing through the area. However, these cadres were remiss in their duties. They did not concentrate on working; left their posts before the end of a working day; and some did not even report for work. The working hours, in other words, were not strictly followed.

The improper enforcement of the law or the abuse of discretion led to the misunderstanding of the policies among the villagers. According to the law, for example, all illegal forest resources (timber or non-timber), and the means of transportation must be confiscated. In practice, however, the FPU only focused their work on the illegal traffic of timber and wild animals, which led local people to conclude that, "only timber exploitation is prohibited while other types of forest resources extractions are not." Consequently, they continued to freely extract non-timber resources.

\section{Lack of human resources}

The duties of the FPU are to patrol, check, and monitor transport routes on land, particularly National Highway No. 7 and the Lam River waterway that runs along the highway. In the study area, only 22 cadres looked after the 105,400 ha of forest that belongs to Con Cuong's territory, the 40-km long National Highway No. 7, and the 40-km long Lam River waterway. This means that one cadre had to take care of an average of 4,800 ha of forest and $3.6 \mathrm{~km}$ of road and waterway, a ratio that made it impossible for them to patrol as well as to effectively manage the area. This is not to mention that one staff member was always in charge of several jobs at a time. FPU cadres themselves admitted that they could not completely check all the vehicles passing through these routes. The lack of personnel thus made it easy for forest extractors to deliver forest products to buyers 
and consumers outside the village.

On the other hand, the patrol teams of the PMNP with a total of only 30 staff members distributed to a total of 9 patrol and checking stations dispersed in the deep forest, had to take care of a huge forest area, or some 190,000 ha of core and buffer zones of the PMNP. On average, each staff member had to take care of more than 6,300 ha of forest. With this limited number of cadres, the SFNCP patrol teams found it difficult to manage, control, and patrol the forest. They also lacked equipment. Forest protectors, for example, could not regularly penetrate deep into the forest because they lacked motorcycles to check out suspected places of extraction. Poor collaboration in forest resource management

Both the PMNP and district people's committee have patrol teams and checking stations. By law, these teams should cooperate in capturing and confiscating illegal forest products. In practice, however, this collaboration was ineffective because one almost never successfully to help another.

\section{Social Networks}

The inability of the state to protect the forest and enforce the law paved the way for villagers to illegally use forest resources as a means to gain additional income. In defiance of state laws, many residents of Lien Dinh have managed to work together as illegal extractors by forging social networks or linkages among fellow villagers or with persons outside the village. These kinds of network, as termed by Peluso (1992:211212), are "underground" ones which are illegal in the eyes of the state. The first set of ties was an internal network, the other was an external one. Internal social networks consisted of ties that village residents made with persons or groups within the village. In turn, external social networks consisted of ties that village residents made with persons or groups outside the village. State officials, interestingly, also involved in this network. The network connected village extractors and traders with outside traders or entrepreneurs. It also covered village traders who, after purchasing goods from fellow villagers, transacted business with outside traders

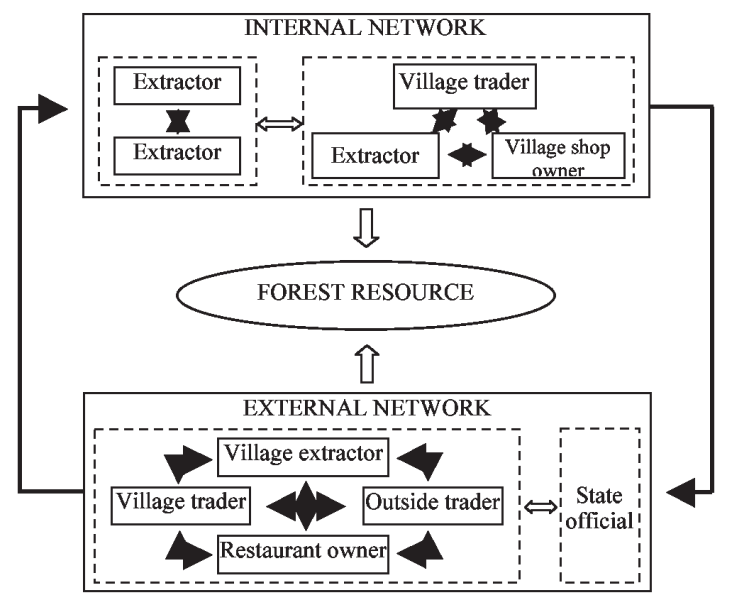

Fig. 2. Social network relationships. or entrepreneurs. The presence of social networks could be seen as the mechanism by which the community engaged in extraction work. Through this engagement, the residents of Lien Dinh have managed to reconstitute their livelihoods as forest dwellers. Figure 2 summarizes networks which helped local people successfully overcome the state's intervention.

\section{Collusion between State Representatives and the Community}

The participation of certain political officials in the community networks implied the presence of collusion or conspiracy between state agents and community residents in forest extraction activities. This collusion is seen in the acceptance of bribes or special favors, in the tolerance shown towards forest extraction activities by the villagers, and in the indirect support of forest extraction of state officials. The acceptance of bribes or special favors and the tolerance, either through promises of economic gain or political intervention, enabled the traders to extract and sell forest resources with less risks of facing sanctions.

Acceptance of bribes or special favors

There were basically two possible ways for traders transporting illegal forest resources to get past a checkpoint station. One was to bribe and the other was a political intervention.

Regarding bribery, forest protectors allowed the trader to pass through the checkpoint if traders or transporters offered an acceptable fee. The acceptable fee was usually decided through a negotiation between the forest protection representative and the trader, transporter, or the forest product-loaded bus conductor. On the other hand, by way of a political intervention, forest protectors allowed forest product-loaded vehicles to pass through the checkpoint station owing to pressures from higher officials of the district, province, or the FPU. Via a phone call to the checkpoint station or via a letter from a powerful official, or from some special signs which were already known in advance, the forest protectors got informed then let a certain vehicle pass through. Tolerance of forest extraction activities by the community people

Personal experience of the researcher illustrated that local officers, specifically the commune chairperson and the policeman, had ignored trucks coming to load timber in the area, even it happened just in front of them. It was obvious that the officers tolerated, and by extension, supported illegal extraction. In addition, according to regulations, a resident who wants some timber to build his house has to seek a permit from the competent authorities. However, villagers simply obtained the logs from the forest and build a house without securing a permit from the authorities. By law, villagers were supposed to be fined for this practice. However, they were not. This is another indication of the tolerance and support shown by state officials.

Indirect support of forest extraction

Despite the state ban on hunting and trading, wild animals were still caught, trapped, and delivered to 
seven specialty restaurants in the district town, where they were cooked as special dishes for patrons to enjoy. The state had been powerless to check on this practice. In fact, state officials took part in this exploitation because they were among the restaurants' regular patrons. In other words, the state officials who were supposed to be in charge of preventing the exploitation and trafficking of forest resources but indirectly supported illegal forest product extraction activities and forest product consumption. Thus, not only were the state policies not strictly implemented, state cadres and officials were among the violators of the laws.

Overall, this collusion systematically weakened the state management mechanism. Tolerance and support of illegal extractions also led local people to have less respect of state policies or regulations as they tended to further exploit forest resources. Despite the implementation of the Program 327 and later the Program 661, and the SFNCP, the forests in Lien Dinh community has experienced an increase of afforested area, a dramatic decrease in the quality of the forest as valuable timber and wild animals rapidly vanished out of the forest and into the lowlands and specialty eateries.

\section{CONCLUSION}

The major findings of the study offer an interesting illustration of Habermas' notion of the relationship between the lifeworld, the system, and the colonization process. In the context of the study, the Vietnamese state can be seen as the system and the community of Lien Dinh as the lifeworld. Through its "steering media" such as policies, programs, and project as well as the money and power embedded in them, the system or the state attempted to manage or colonize the village's or the lifeworld's activities. In particular, those activities were that the state deemed as harmful for the environment or interpreted as violations of the system's interests. Among these activities were timber and NTFP extraction. These state policies, programs, and project, in so far as they presented an orientation and a set of procedures to protect forest resources, thus, represented a kind of rationality imposed by the state on local communities like Lien Dinh. The degree in which local communities abided by this new kind of rationality may be seen as the degree to which lifeworlds have been colonized by the system. The greater the extent in which a local community follows state-sanctioned forest practices, the more colonized that local community is. The degree of colonization, however, never took place in Lien Dinh. In fact, villagers have subverted the colonization process and have reconstituted their forest extraction activities. The networks they have built to reproduce forest extraction work have considerably grown given that the forest environment has become more degraded than before.

Why did the subversion of the colonization process take place? The answer lies in Habermas's (1973:74-75) notion of "legitimation crisis," which he defines as "a discrepancy between the need for motives declared by the state, the educational system, and the occupational system on one hand, and the motivation supplied by the socio-cultural system [lifeworld] on the other." Pusey (1993:95) elaborates on this concept when he says that "a [legitimation] crisis may occur if any one of the subsystems fails to produce 'the requisite quantity' of what it contributes to the whole." In Lien Dinh village, the legitimation crisis arose from three major system faults. The first is the failure of decrees, programs, and project to provide sustainable alternatives to people's livelihood and their sense of security towards their lands. Lien Dinh villagers, therefore, continued to use forestland and forest resources as their main source of livelihood and income. The second is the inability of the state's forest protection agencies to effectively control illegal forest extraction, because the state could not deploy a large cadre of well-disciplined and well-motivated officers to patrol in the forests, on the highways, and on the river. The third, and perhaps the most serious system fault, is the participation of local state officials in illegal forest extraction activities, specifically as part of the local "underground" or illegal networks that supply forest products to outside traders. These system faults made visible to local communities the large cracks of the system's political machinery and rendered that machinery inconsistent, contradictory, and inutile. Likewise, the combination of networks and the poor or weak state control kept low the risk of being caught in the illegal forest extraction activities of the villagers. Thereafter, it was easy enough for forest extractors to pay off officials, elude arrest, and risk punishment. By subverting the colonization process of the state, and by resisting state power in gaining access to the forest, the villagers of Lien Dinh community have been able to reconstitute their forest livelihood.

\section{ACKNOWLEGDMENTS}

The paper is part of Master thesis of the first author completed in 2003. The authors would like to thank local people, state officials and especially villagers, in the study area for their contribution and help. We also express our thanks to the Ford Foundation for its funding for the study.

\section{REFERENCES}

Bellamy, Ruffus 2000 Assessing Different Approaches to Forest Management in Vietnam. International Development Research Centre, Ottawa, Canada

Castella, Jean-Christophe et al. 2002 Impact of Forestland Allocation on Agriculture and Natural Resources Management in Bac Kan Province, Vietnam. In "Doi Moi in the Mountains: Land use changes and farmers' livelihood strategies in Bac Kan Province, Vietnam.”, ed. by Castella, J. C. and Quang, D. D. The Agricultural Publishing House, Hanoi, Vietnam, pp. 197-220

CPC (Chi Khe Commune People's Committee) 2002 Annual Report 2001. Nghe An, Vietnam

Cuc, Le Trong et al. (eds) 1996 Red Books, Green Hills: The Impact of Economic Reform on Restoration Ecology in the Midlands of Northern Vietnam. CRES, Hanoi 
University; Southeast Asian Universities/Agroecosystem Network; East-West Center/Program on Environment: University of California at Berkeley

Decision 661/QD-TTg 1998 Objectives, Tasks, Policies and Implementations of the Five-million-hectare Afforestation. Prime Minister of Vietnam, Vietnam

Decree 01/CP 1995 The Enactment of Regulations the Allocation of Land for Agriculture, Aquaculture, and Forestry in State-run Enterprises/Farms to Organizations, Households and Individuals for Stable and Long-term Use. The Central People's Government, Hanoi, Vietnam

Decree 02/CP 1994 The Enactment of Regulations on the Allocation of Forestry Land to Organizations, Households and Individuals for Stable and Long-term Use for Forestry Purposes. The Central People's Government. Hanoi, Vietnam

DPC (Con Cuong District People's Committee) 2002 Annual Report 2001. Nghe An, Vietnam.

FPD (Forest Protection Department) 2006 Annual Report 2005. Hanoi, Vietnam

Habermas, Jurgen 1973 Legitimation Crisis. Boston: Beacon Press

Habermas, Jurgen 1984 The Theory of Communicative Action - Reason and the Rationalization of Society. Vol. 1. Boston: Beacon Press

Habermas, Jurgen 1987 The Theory of Communicative Action - Lifeworld and System: A Critique of Functionalist Reason. Vol. 2. Boston: Beacon Press

Howard, Caroline 1998 Forestry Transition in Vietnam. Commonwealth Forestry Review, 77(4): 249-253

Huy, Bao 2003 Participatory Technology Development on Natural Forests Allocated to the M'nong Ethnic Community. Social Forestry Support Program. Tay Nguyen University, Vietnam

MARD (Ministry of Agriculture and Rural Development) 2003 Annual Report 2002. Hanoi, Vietnam

Nhan, Thanh 1998 Forestry - A Way to Improve the Lives of Mountain People (in Vietnamese). Hanoi, Vietnam: Forestry Magazine (Sept. edition), Vietnam. pp. 8-16

Peluso, Nancy Lee 1992 Rich Forest, Poor People: Resource
Control and Resistance in Java. University of California Press, Berkeley

PMNP (Pu Mat National Park) 2001 Annual Report 2000 Hanoi, Vietnam

Pusey, Michael 1993 Jurgen Habermas - Key Sociologists. London: Routledge

San, Nguyen Van and Gilmour, David 1999 Forest Rehabilitation Policy and Practice in Vietnam. IUCN Hanoi, Vietnam

SFNCP (Social Forestry and Nature Conservation Project) 2002 Data of a Participatory Rural Appraisal Survey in Lien Dinh Village. Nghe An, Vietnam

Sunderlin, William D. and Ba, Huynh Thu 2005 Poverty Alleviation and Forests in Vietnam. Center for International Forestry Research (CIFOR). Indonesia. pp. 73

Thanh, Nguyen Xuan et al. 2000 Issues Concerning Forestland Allocation to the San Diu Ethnic Farmers in Bac Giang (in Vietnamese). Hanoi Agriculture University, Hanoi, Vietnam

Thanh, Tran Ngoc 2001 Participation in Land Use zoning, Forestland Allocation and Management in Dak Phoi, Dak Lak (in Vietnamese). MRC/GTZ Sustainable Management of Resources in the Lower Mekong Basin Project, Dak Lak, Vietnam

Thu, Nguyen Thi 1999 Socioeconomic Situation of the Tay Ethnic Minority in Bac Giang Province (in Vietnamese). Hanoi Agricultural University, Hanoi, Vietnam

Tuan, Khuong Ba 1998 Incentives for Forest Owners after Forest Land Allocation in Thanh Hoa Province (in Vietnamese). Thanh Hoa, Vietnam

Vien, Tran Duc, Quang, Nguyen Vinh, and Thanh, Mai Van 2005 The Impacts of Decentralization of Forest Management and Livelihoods of Ethnic Minority Groups in the Northwestern and Northern Central Uplands of Vietnam. The Agricultural Publishing House, Vietnam, pp. 124

Viet, Pham Van 1998 The Community Forest Management Strategy of the SFDP Song Da. SFDP Song Da, MARD, GTZ-GFA, Hanoi, Vietnam

World Bank 2002 Vietnam Environment Monitor 2002. The World Bank in Vietnam, Vietnam 